Socialist Studies / Études socialistes 8 (1) Winter 2012

Copyright $\odot 2012$ The Author(s)

\title{
Books Reviewed
}

Warner, Tom. 2010. Losing Control: Canada's Social Conservatives in the Age of Rights. Toronto: Between the Lines. Reviewed by Lorna Erwin.

Kinsman, Gary and Patrizia Gentile. 2010. The Canadian War on Queers: National Security as Sexual Regulation. Vancouver: UBC Press. Reviewed by Mathieu Brûlé.

Thompson, Jon. 2011. No Debate: The Israel Lobby and Free Speech at Canadian Universities. Toronto: Lorimer. Reviewed by Alan Sears.

Pawley, Howard. 2011. Keep True: A Life In Politics. Winnipeg: University of Manitoba Press. Reviewed by Errol Black.

Stewart, Roderick and Sharon Stewart. 2011. Phoenix: The Life of Norman Bethune, Montreal: McGill-Queen's University Press. Reviewed by Ken Collier.

Lilley, Sasha. 2011. Capital and Its Discontents: Conversations with Radical Thinkers in a Time of Tumult. Reviewed by Thom Workman.

McNally, David. 2011. Global Slump: The Economics and Politics of Crisis and Resistance. Oakland: PM Press. Reviewed by Bill Burgess.

McBride, Stephen and Heather Whiteside. 2011. Private Affluence, Public Austerity: Economic Crisis and Democratic Malaise in Canada. Halifax: Fernwood. Reviewed by Joan McFarland.

Harvey, David. 2010. The Enigma of Capital and the Crises of Capitalism. New York: Oxford University Press. Reviewed by Matthew Brett.

Olsen, Gregg M. 2011. Power and Inequality: A Comparative Introduction. Don Mills: Oxford University Press. Reviewed by Larry Patriquin.

Livingstone, David; Dorothy Smith and Warren Smith. 2011. Manufacturing Meltdown: Reshaping Steel Work. Halifax: Fernwood. Reviewed by Ann Duffy.

Camfield, David. 2011. Canadian Labour in Crisis: Reinventing the Workers' Movement. Halifax: Fernwood. Reviewed by Stephanie Ross.

Webber, Jeffrey. 2011. From Rebellion to Reform in Bolivia. Chicago: Haymarket Books. Reviewed by Manuel Larrabure.

Post, Charles. 2011. The American Road to Capitalism: Studies in Class Structure, Economic Development and Political Conflict, 1620-1877. Leiden: Brill. Reviewed by Jordy Cummings.

Bannerji, Himani. 2011. Demography and Democracy: Essays on Nationalism, Gender and Ideology. Toronto: Canadian Scholars' Press. Reviewed by Aziz Choudry.

Wright, Erik Olin. 2010. Envisioning Real Utopias. London: Verso. Reviewed by Jeff Noonan.

Socialist Studies / Études socialistes:

The Journal of the Society for Socialist Studies / Revue de la Société d'études socialistes.

www.socialiststudies.com. ISSN 1918-2821 
Warner, Tom. 2010. Losing Control: Canada's Social Conservatives in the Age of Rights. Toronto: Between the Lines. ISBN 978-1-897071-41-0. Paperback: 29.95 CAD. Pages: 292.

Reviewed by Lorna Erwin

York University

Now that a majority Conservative government has taken its place in Ottawa, what can we anticipate from the religious right? To judge from the volume under review, which was published in 2010 (before, that is, Stephen Harper's unexpected triumph), there is every expectation of fresh assaults on Canada's secularist and rights-centred political culture. Having effectively lost control of the country's moral agenda, amidst four decades of strident resistance to abortion, gay rights, and related issues, Canada's social conservatives, according to Tom Warner, nevertheless remain an "impressively organized and dynamic opponent" (vii). Moreover, "the holy war" (4) they continue to wage shows "no shortage of political support" (221).

And now, of course, as of May, 2011, such support would seem to bulk even larger. Warner, a prominent activist and spokesperson on gay issues in Ontario who once served on the province's Human Rights Commission, claims simply to offer a snapshot of the political landscape in 2010. Actually he does a good deal more, building his case for vigilance with a meticulous review of the police raids and prosecutions, the legal and theological arguments, and of course the government reactions that constitute Canada's record of human rights advances and retreats over the past forty years.

That it has mostly been a record of advances is readily acknowledged by the author-that, indeed, is why the undiminished anger and determination of the religious right must not be ignored, despite the seemingly overwhelming defeats it has suffered. Warner's chief concern, in any case, is with the mobilization of evangelical forces, beginning in 1970s, as their social status and political clout come under attack amidst the dawning of what Warner (following Chief Justice, Beverly McLaughlin), refers to as Canada's "Age of Rights." The hateful tirades that began during this period, the dire and, at times, even apocalyptic warnings - who today recalls any of this in connection with the rapid mobilization of the anti-abortion forces prior to the Charter, or for that matter the Trudeau government's embarrassing attempts at appeasement of these forces?

Clearly the struggle to decriminalize abortion and to sustain women's freedom from harassment in exercising their reproductive rights could easily sustain a book-length study. Failing that we are fortunate to have Warner's detailed chapter on the on-going pro-life/pro-choice struggle. His book's illuminating accounts of the trials and appeals that underlie Canada's changing definitions of obscenity and the multi-faceted efforts to secure gay rights are likewise welcome. Perhaps the most arresting chapter is on what the Manning Centre for Building Democracy might call the interface between pulpit and 
politics. That Preston Manning, Harper and their media allies have been at pains to impose discipline on their Christian right supporters, even while denying that such supporters pose any threat to mainstream values and institutions is well documented in Losing Control. Like Marci McDonald, in The Armageddon Factor (Random House Canada, 2010), which covers some of the same ground, Warner quite plausibly sees such stealth and denial as an essential ingredient of social conservative advance.

What Harper has done for the religious right since becoming prime minister in 2006- his cancellation of the Court Challenges Program and gay pride funding, for example, or his exclusion of abortion services from his government's G-8 initiative on maternal health-hasn't generated a lot of controversy, which of course is precisely the point from the Conservative perspective. Nevertheless the question that can't be evaded is this: can a prime minister determined to make the Tories into Canada's natural governing party dare to turn the clock back on same-sex marriage legislation? And with support for abortion rights in Canada running to somewhere between 55 to 78 percent, can anything significant be done to appease those restive Catholics and evangelical Protestants who insist on reopening the debate?

Not surprisingly, Losing Control doesn't offer clear-cut answers to such questions. But it does typically inform us, in a final chapter titled "Faith, Politics, and the Transformation of Canada" that "pro-life groups remain formidably active" (246). It is here that my reservations begin. For unfortunately Warner's almost exclusive focus on organizational activities and noisy, attention grabbing statements leaves the social and political contexts of the activities he is writing about badly out of focus.

Where, in other words, are the statistics in this volume on trends in evangelical church membership or voting intentions in Canada? Or the comparisons with similar developments in the United States, where of course the polarization wrought by the religious right is especially acute. Warner does cite data from an academic source suggesting that slightly more than a quarter of Canadian voters in 2000 were inclined to identify themselves as social conservatives, and he throws in another poll from a religious organization to the effect that 19 per cent of Protestants and seven per cent of Catholics in Canada see themselves as "evangelicals." But, in the absence of longitudinal data on religious and political trends, such "snapshots" tell us little.

Warner's principal way of accounting for the growth of social conservatism is to point to the Charter of Rights and Freedoms. More precisely, it is the success of the feminist and the gay and lesbian liberation movements, driving a rights-based political agenda made possible by the Charter, to which Warner attributes the moral backlash of the right. This is not so much wrong, in my view, as incomplete-especially inasmuch as it begs so many questions about changes in work and family roles. How, for instance, does the decline of teen-age pregnancy, abortion and divorce among the increasing numbers of women who attend college or university factor into the abortion debate? 
At the dawn of a Conservative majority, it isn't only our Charter rights that are threatened. A hollowing out of health care and other social programs may well be expected, with devastating consequences for vulnerable families. And can anyone hope that our abysmal record on the environment is likely to improve? The point is that the Canadian left and its liberal allies have limited energies and resources. The author of this volume does well in recounting the hallmark struggles of the past and in likewise issuing a timely warning for today. But we need to know more about the social underpinnings of the "holy war" that confronts us, if we are to respond effectively to the stark choices we face.

Kinsman, Gary and Patrizia Gentile. 2010. The Canadian War on Queers:

National Security as Sexual Regulation. Vancouver: UBC Press. ISBN 978-

0-7748-1628-1. Paperback: 34.95 CAD. Pages: 554.

Reviewed by Mathieu Brûlé

York University

In The Canadian War on Queers: National Security as Sexual Regulation, Gary Kinsman and Patrizia Gentile set out to "change Canadian history" and challenge "current Canadian historiography" by basing their analysis on "previously excluded and denied social experiences, making visible what was invisible and giving voice to what was silenced" (6). This is an ambitious goal, but one which they have managed to achieve, at least to an extent. Whether this book has altered the course of Canadian historiography remains to be seen, but where Kinsman and Gentile succeed is by bringing to light the voices that have until recently been absent from the historical record. The revelation that queers faced repression at the hands of the Canadian state is not an entirely original finding. While issues of surveillance in the post-war period have been previously raised (not least by Kinsman and Gentile themselves in previous works), The Canadian War on Queers adds a new perspective by focusing on the voices of individuals targeted by national security campaigns that sought to uncover and remove queers from the public service and armed forces. This study provides glimpses into the post-war queer communities and networks that the Canadian state sought to infiltrate, as well as the ways in which these communities developed strategies of resistance to expose and neutralize the RCMP and local police efforts to expose them.

The more than fifty interviews, combined with diverse national security documents obtained through access to information requests, provide the foundation for 
this work. Through these documents, Kinsman and Gentile are able to demonstrate that the regulation of sexuality and the subsequent "war on queers" was an integral, systemic and ideological feature of the Cold War national security campaigns. It was the construction, in public discourse, of gender and sexual non-conformity as threats to social stability that allowed the state to subsequently construct queers as threats to national security. The belief that same-gender attraction was a character weakness provided the basis for the argument that this weakness could be exploited by foreign agents seeking to blackmail queer public servants. While the campaigns to remove queers from the civil service abated by the late 1970s, Kinsman and Gentile demonstrate how these efforts continued in the military well into the 1990s, as well as the lengths to which the state went to identify them. From infiltrating and photographing civil servants in downtown Ottawa's gay bars, to developing the infamous "Fruit Machine," the effort and energy the state invested in detecting and dismantling queer networks demonstrates the extent to which they felt people who engaged in same-gender relationships posed a threat to the security of the nation.

Kinsman and Gentile's extensive discussion of the lesbian and gay liberation movements of the 1970s is also a welcome contribution to the growing number of studies on these movements in Canada. One of the principal contributions of this chapter, aside from shedding light on the surveillance these movements underwent, is on their relationship with the leftist movements of that era and the extent to which the lesbian and gay movements emerged from these groups. Although the excerpts from national security documents provided in the book suggest that lesbian and gay liberation activists were targeted for their leftist affiliations rather than their sexualities, scholars and community historians interested in this era of queer activism will benefit from Kinsman and Gentile's decision to include a discussion of these movements in their work.

In addition to its contributions to the scholarship on post-war Canada, The Canadian War on Queers also has a political agenda, which the authors make clear from the dedication through to the closing chapter of the book. Kinsman and Gentile hope that their research will serve as a wake-up call to mainstream lesbian and gay communities who are openly supportive of current national security campaigns against marginalized groups, including sex workers, Arabs, Muslims and even other queers. They hope that their research will serve as a reminder that the national security campaigns that defend the "heterosexist character of Canadian state formation" and once constructed queers as threats to national security continues to do the same today (434). While the use of discipline-specific language might turn some of their intended audience away, their efforts to use their research to affect public discourse surrounding issues such as national security will be appreciated.

The use of the research to shape public discourse is not the only way in which Kinsman and Gentile push the boundaries of professional historical writing. The decision to include short paragraphs, printed in a distinct font, in which Kinsman relates his 
personal experiences with some of the events described in their work, also stands out as a novel technique in historical scholarship. While this may be a common technique in some disciplines, historians of the recent past tend to be much more wary of blurring the line between scholar and subject. Although some of these paragraphs seemed distant from the topic at hand and give the reader the impression that they were included for their own sake, the authors' decision to do so adds an interesting anecdotal element to the narrative. It could also stand as a challenge to historians of the recent past to not shy away from telling their own stories. Scholars have their own life experiences that can inform the topics we study. To let these stories go untold would contradict the very purpose that pieces of scholarship like The Canadian War on Queers set out to accomplish: that is, to tell the story from the bottom-up.

Thompson, Jon. 2011. No Debate: The Israel Lobby and Free Speech at Canadian Universities. Toronto: Lorimer. ISBN 978-1-55277-656-8.

Paperback: 22.95 CAD. Pages: 334.

Reviewed by Alan Sears

Ryerson University

The central strategy of Israel advocacy organizations on Canadian campuses has been to make Palestine unspeakable and to silence criticism of Israeli policies outside of narrow limits. One important moment in this silencing campaign was the attempt to shut down the conference entitled "Israel/Palestine: Mapping Models of Statehood and Paths to Peace” at York University (co-sponsored by Queen's University) in 2009.

This book is the report of an Inquiry commissioned by the Canadian Association of University Teachers (CAUT) into the attempts to shut down the conference and the responses by York University administrators, the Harper government and the Social Sciences and Humanities Research Council (SSHRC) which had awarded the conference a grant. The Inquiry was conducted by Jon Thompson, an academic freedom expert who is a professor emeritus in the Department of Mathematics and Statistics at the University of New Brunswick.

This Inquiry was thorough, methodically documenting the events surrounding the conference, particularly in intense lead-up period from April to June 2009. The role of individual York administrators is thoughtfully evaluated. The York administration is generally given credit for consistent application of the principles of academic freedom, in that the conference actually went ahead with official, if at times equivocal, support. 
Individual administrators (Associate Vice President David Dewitt and Osgoode Hall Dean Patrick Monahan) were found to have acted inappropriately in specific instances. The Inquiry carefully sifts through their actions, noting in both cases that there were also times where they acted appropriately in ways consistent with academic freedom. There is much to be learned in this analysis about the role of university administrators, and particularly the complex balance between their own academic freedom as faculty members and their official role as protectors of the freedom of others on campus.

The Harper government, meanwhile, was found to have seriously violated principles of academic freedom in ways that are deeply disturbing. They directly interfered in the conduct of SSHRC, an arms-length agency, asking for an extraordinary second peer review of the conference grant. While SSHRC did not accede to this request, it did demand an extraordinary pre-conference accounting from the conference organizers. This direct political interference, and the equivocal response of SSHRC, is a serious threat to academic freedom on Canadian campuses, and a huge challenge to faculty associations, academic institutions and scholarly organizations of all descriptions.

I read this book with interest, and by that I mean both that I found it compelling and that I was not disinterested as I am an active member of Faculty for Palestine who attended the Mapping Models conference. I position myself in this discussion in order to address an earlier review of this conference, conducted at the behest of the York University administration by former Supreme Court of Canada justice Frank Iacobucci. The Iacobucci report not only included unwarranted criticisms of the conference organizers, but also reframed academic freedom in extremely narrow terms. Iacobucci distinguished between "professional activists" and "legitimate' academics," suggesting that academic freedom applies only to specific scholarly activities. According to the Iacobucci framing of academic freedom, my expression in writing this review would not necessarily be protected as I am neither disinterested nor writing within my professional field of expertise. Thompson argued that the implementation of the Iacobucci recommendations at York "could represent a serious adverse precedent for academic freedom in Canada." (295)

The recommendations of Thompson's CAUT Inquiry are rightly directed largely at getting faculty associations to organize and build alliances to resist the precedentsetting political interference of the Harper government and the dangerous narrowing of the frame of academic freedom supported in the Iacobucci report. This book is an essential tool in those mobilizing efforts and members should be getting our own associations to purchase and distribute this book, encourage discussions on its contents, and support measures to defend academic freedom.

The silencing offensive to make Palestine unspeakable aligns in important ways with the neo-liberal transformation of the post-secondary system, which is being more closely aligned with the needs of corporations in part through political direction by the 
state. Academic freedom risks being cast as an inconvenient fetter on the untrammeled commercialization of universities and their reorientation towards providing the human resources and innovative intellectual properties to drive corporate profitability.

This silencing campaign must be opposed because it opens the door to wider attacks on academic freedom at a time when such attacks are to be expected. But it should also be opposed in the name of justice for Palestinians, including their academic freedom which is constrained by conditions of occupation, exile or second-class citizenship within the State of Israel.

The organizers of the Mapping Models conference did the important work of bringing together key experts engaged in leading edge debates about possible solutions to the issues in Israel/Palestine. The conference was not balanced in that it was a presupposition of its framing that any real solution to the issues in the region must genuinely address the historic claims of Palestinians.

The solutions currently on the negotiating table do not meet this criterion, and are unlikely to be acceptable to the bulk of Palestinians even in the unlikely event that the Israeli state were to seriously pursue negotiations. This is why over 170 Palestinian civil society organizations issues a call for a global campaign of boycott, divestment and sanctions against Israeli institutions on July 9, 2005, a year after the International Court of Justice issued an advisory opinion on the illegality of Israel's Wall in the Occupied Palestinian Territories. At very least, this call must be debatable on our campuses and in our communities, or we will have utterly failed the test of defending academic freedom and supporting justice for Palestinians.

Pawley, Howard. 2011. Keep True: A Life In Politics. Winnipeg: University of Manitoba Press. ISBN 978-0-88755-724-8. Paperback: 27.95 CAD.

Pages: 278.

Reviewed by Errol Black

Canadian Centre for Policy Alternatives - Manitoba

Howard Pawley, the premier of Manitoba from 1981 to 1988, has written an interesting and important book documenting his life as a politician of the left during an era which saw the rise of the New Right and neoconservatism in Canada. Along with the insights we get into Pawley's character, we learn much about the New Democratic Party (NDP) as Manitoba's dominant political party. 
Pawley joined the Manitoba Co-operative Commonwealth Federation (CCF) in 1954, and in 1957, at the age of 22, became both organizer and party president. Early on, he characterized himself as a democratic socialist and activist. Notably, he challenged changes in party policy and direction that he thought detrimental to the party's development and future. He opposed the Winnipeg Declaration of 1956 on the grounds that it was "a watering-down of the anti-capitalist principles of the Regina Manifesto" (13) and the formation of a new party because he feared domination by organized labour would compromise the movement.

The NDP's 1969 election victory was a watershed in Manitoba politics. For two terms, Ed Schreyer and the NDP provided a competent, progressive, social democratic government for the people of Manitoba. As a rookie Member of the Legislative Assembly, Pawley became the Minister of Municipal Affairs and was given the task of establishing public auto insurance. In the face of strong opposition, Pawley and the government stood fast and prevailed: "It was our belief that the NDP, a populist Left movement, often operates best when from time to time it confronts those among the most wealthy and powerful in society" (32).

During its second term, however, the government's acceptance of federal wage and price controls and its failure to deal decisively with a bitter and protracted strike at Griffin Steel Industries in Transcona in 1976-77 cooled labour's enthusiasm for the government. The NDP lost the 1977 election to a Progressive Conservative (PC) Party led by Sterling Lyon that campaigned on a platform of fiscal and social conservatism - a harbinger of the neoconservative onslaught to come.

Elected NDP leader in 1979, Pawley reached out to the party's grassroots, insisted that economic issues be front and centre in the campaign and worked to repair the damaged relationship with organized labour. He also became more sensitive, he observes, to achieving a balance between principles and pragmatism. He learned "that I would have to choose between a socialist party leading public opinion and being more pragmatic. Not everything we seek can be achieved in the short term.... This does not mean, however, betraying one's ultimate objective - a more equitable society" (103).

In the 1981 election, the NDP returned to power. As Canada sunk into a serious recession, the NDP responded with a multi-faceted counter-recessionary program based on a social contract with the Manitoba Government Employees Association, a Jobs Fund and an acceleration of capital projects (especially Hydro projects). Pawley explains that these "programs reflected a social democratic philosophy whose objective was to gradually reduce sharp disparities in income distribution" (136). The favourable performance of the Manitoba economy relative to other provinces reflected, in large part, the impact of this program.

The government faced other significant challenges. The most serious was the language controversy which had its roots in the overturning by the Supreme Court of a law passed in 1890 that denied French language rights in Manitoba. The Pawley 
government rectified this situation in the face of bitter opposition from the PCs and other conservative forces. Pawley understandably refers to this battle as "a political nightmare" (chapter 6).

Despite these challenges, the government pushed for improvements in labour legislation and employment standards, including First Contract legislation, pay equity legislation, increases to minimum wage and social assistance, and changes to the Workplace Health and Safety Act to ensure workers "the right to know, the right to refuse, and the right to participate" (170).

After the 1986 election, the NDP was reduced to a slim majority. The Pawley government continued to bring forward progressive reforms, including the inclusion of sexual orientation in the Human Rights Code, new environmental legislation and Final Offer Selection as an option to settle labour disputes involving small bargaining units with little power.

Federal-provincial relations were difficult. This was particularly true of Brian Mulroney's treachery involving the CF-18 aircraft maintenance contract; the Canada-US Free Trade Agreement, which was opposed by Pawley and his government; and the Meech Lake Accord, which was endorsed by Pawley, but was rejected by the party and ultimately met its demise in Manitoba because of the actions of NDP members in the legislature under a PC government. In summing up his experience of intergovernmental relations, Pawley admits that he was the "odd guy out,' perceived by [Mulroney and] many of my colleagues as too left-wing and confrontational" (205).

The government's popular support was undermined by growing opposition to the Meech Lake Accord, big increases in auto insurance rates and - following Keynesian principles - rising taxes with a more robust economy to reduce deficits and debt. Pawley's government was done in when Jim Walding, previously passed over for a cabinet position, voted on 8 March 1988 with the opposition against the government's budget. As a result, Pawley resigned as premier and party leader. In the ensuing election, the NDP, led by Gary Doer, was reduced to 12 seats.

There is much to be learned from this book about Pawley, the NDP and political life in Manitoba during his time in politics. From 1969 on, the NDP was, for all intents and purposes, the left in Manitoba, with most party members identifying themselves as democratic socialists committed to using the powers of an activist state to reduce inequalities in income and power. This commitment was reflected in policy agendas that resulted in significant improvements in the material conditions of individuals and families at the bottom of the income distribution, greater rights for women and minorities, and labour law reforms that strengthened the labour movement and improved the lot of all workers. There was, within the party, an appreciation of both the need to build the party on an ongoing basis and the importance of annual conventions to bring together party activists to debate principles and policy. Along with this, there was also an appreciation of the vital relationship between the party and labour. 
The NDP regained power in 1999. The NDP government, re-elected to a fourth consecutive term in October 2011, continues to lead the country with new policies and programs of a progressive nature. At the same time, however, there is a recognition that the party has moved to the right on fiscal and social issues in the 23 years since Pawley retired. There is, moreover, greater emphasis on winning elections as opposed to building the party and the movement. The vision has dimmed. As a consequence, the local constituency associations have become more subdued.

The question that is left after reading this book is: can the NDP rediscover its democratic socialist vision of equality and rejuvenate its politics? It is important to continue to win elections; but can the NDP do that while maintaining the democratic socialist vision that characterized Pawley's political practice?

Stewart, Roderick and Sharon Stewart. 2011. Phoenix: The Life of Norman

Bethune, Montreal: McGill-Queen's University Press. ISBN 979-0-7735-

3819-1. Cloth 39.95 CAD. Pages: 479.

Reviewed by Ken Collier

Society for Socialist Studies

Canadians may not often consider who is the best known of us around the globe. Arguably, this figure is the focus of Roderick and Sharon Stewart, who present a chronological account of Dr Norman Bethune's colourful, explosive, unpredictable and contradictory life from birth and upbringing to a rather disorderly university career, where Bethune's sheer brilliance and exuberant personality pushed him past pitfalls that would have sidelined most others. Subsequent chapters follow Bethune in 1936-37 to the Spanish Civil War, then to China in 1938-39. He performed breathtaking surgical feats and created war-front health services credited with saving thousands of lives during two of the greatest defining revolutionary upheavals of the $20^{\text {th }}$ Century. In China, he is officially revered, having statues, museums and publications honouring him.

Struggles persist over interpretation and facts in the previously best-known Bethune book The Scalpel, The Sword: The Story of Dr. Norman Bethune (McClelland and Stewart, 1952) and the films (two of them starring Donald Sutherland). Churches, leftwing and socialist political parties and the governments of Canada, Spain and China, made competing claims throughout the Cold War about Bethune's legacies on three continents. So Roderick Stewart, author of a prior biography, joined now by his wife Sharon, felt drawn back into the Bethune maelstrom to correct misinformation and to render as level an account as partisans are able, presenting and documenting materials that had often been subjected to fast-and-loose treatment. Where they can't prove a point, 
they admit it. Where the volume of material is too large, such as that dealing with the motives driving such varied authors on Bethune or China as Ted Allan, Agnes Smedley, Edgar Snow and former Canadian Governor General Adrienne Clarkson, among others, it likely had to be set aside for future research.

Bethune's public story began as he decided to join the Republican forces in the Spanish Civil War. He wanted to open surgeries close to the battle lines to prevent the loss of lives of the wounded caused by delays and lack of skilled treatment. Frightening numbers died because they lost too much blood, got gangrene or were given wrong (or no) drugs. Bethune's Communist commitment and the fascist threat drove him to demand that money be raised to set up surgeries and mobile blood clinics, where he often conducted direct person-to-person transfusions, using his knowledge of field testing for blood type compatibility. Patients were carried back to hospitals he organized, often peasant's houses or any shelter left standing. He frequently gave the wounded his clothing and food.

Though often credited with inventing mobile blood banks and army surgical units, it is more accurate to say Bethune learned of the techniques invented by others and adapted them to the ferocious realities of, for example, the road to Almería in Spain, where, in addition to field surgery, he photographed and wrote as the sole journalist about the agonies of streams of refugees just trying to stay alive.

Mercurial characters like Bethune draw admirers and opponents. The Spanish adventures created tensions there and in Canada. His often atrocious behaviour got in the way just as much as the practical realties of fighting fascism. When Bethune returned from Spain to Canada on a fund-raising tour, political manoeuvring prevented his return. With the support of the Communist Party of Canada and solidarity organizations, Bethune swiftly turned his focus to China.

In the anti-fascist struggle against Japan, which drove the Guomindang and the Communists together in a common front, Bethune shouldered new responsibilities, becoming the phoenix of legend and of his own writings. Creating and adapting methods rarely seen in remote and war surroundings, he saved lives and taught hundreds of Chinese peasants how to do the same while the artillery boomed and the bullets whistled. Bethune died of physical strain, exhaustion, poor diet and ultimately from one of several infections in his limbs after he cut himself during an operation near the front.

The Stewarts present a supported, detailed account of Norman Bethune's meteoric career. Their controlled but obvious admiration for the man fuels the story and its accuracies. It is doubtful that a final definitive Bethune book can be compiled, for the contexts of political struggle, personal life and motivation, technical, medical and organizational skill in war and other currents created continuing turbulent and conflicting images of this very complicated man.

The Stewarts breeze by Bethune's Communist Party activities. Though they note the theoretical literature he always had with him, there is no mention of the conclusions 
that Bethune drew from it. Archives likely hold some Bethune's notes on Marxist ideas, but Phoenix portrays little more than his "man of destiny" approach to Communism. If that is all there was, it has some important implications for the Communist Party of Canada and how they accepted him, employed his skills and personality and folded him into the party apparatus in much more flexible ways than the usual party stereotype.

There is some unfortunate messiness in the book. A map listed on the wrong page in the table of contents has no legend, so you only discover that a certain kind of line is a railroad from either close reading of the text or reference to another map more than 100

pages earlier. Another map is missing towns named in the adjacent text, making it hard to follow the route and the chronology of Bethune's war marches. Wonderful pages of photographs appear, unannounced in the table of contents. The name of the woman Bethune married twice is misspelled twice. It may be understandable that Chinese place names have different English spellings, but they sometimes occur on the same page. Some people and topics appear in the index, others do not.

On the other side of these minor complaints, reading the admirable endnotes independent of the text conveys a story in itself. Detailed and pointed, they tell of important events and trends in the Communist Parties (of Canada, of China and of the USA), in government and in the political culture of the times.

Part of the fitting conclusion sums up a sparkling personage: "Bethune's life exhibits recurrent cycles of achievement and self-destruction - the pattern of the phoenix. He was a born crusader, and the evangelistic spirit created by his Christian upbringing later informed his developing social consciousness and his ultimate faith in communism" (375).

Lilley, Sasha. 2011. Capital and Its Discontents: Conversations with Radical Thinkers in a Time of Tumult. Oakland: PM Press. ISBN: 978-1-60486334-5. Paperback: 21.95 CAD. Pages: 279.

Reviewed by Thom Workman

University of New Brunswick

Capital and Its Discontents: Conversations with Radical Thinkers in a Time of Tumult is well worth the read, but is likely to be much more alluring to initiated readers. In this new book, journalist Sasha Lilley interviews many of the luminaries on the left today including Noam Chomsky, Ellen Meiksins Wood, David Harvey, Mike Davis and Leo Panitch. Seventeen different writers are interviewed in all. The range of themes 
surveyed include the crisis of global capitalism, the rise of neoliberalism, militarism and imperialism, the looming ecological catastrophe, and the acute failure of capitalist development across the majority world.

Lilley's interviews show that she is in complete command of the main ideas and contributions of each writer. The interviewees are invited to reflect and expand on their ideas familiar to many of us on the left. The semi-formal nature of the interviews gives these expansions a fresh feel, and it is compelling to get a sense of the suppositions impelling certain notions and claims. Lilley's questions are posed with an impressive clarity yet she avoids too much "voice-leading." The pace and tone of the interviews are relaxed despite the fact that they never lose their theoretical coherence. The interviews are as solid as this format can get. Anyone who has had a brush with a typical journalist will quickly reflect on the pleasure it would be if all interviews were conducted by such theoretically informed, perspicacious interviewers.

Capital and Its Discontents coheres around the notion that capitalism's tendency towards immanent crises has created an incompatible cultural disjunction and an odd sort of political paralysis. The Freudian notion-implied by the title-of a basic tension between the instincts on the one side and repressive Western culture on the other endures in the notion of a contradiction between neoliberalism with its grievous social injuries and the incapacity of the cultural and political world to respond effectively. Something must give and will give. Neoliberal society is one where a latent anger with the prevailing capitalist order of things manifests itself at numerous turns, yet fails to coalesce into a sufficiently formed political movement capable of challenging the course of things. Capital and Its Discontents brings this tension to the surface in a theoretically and empirically sustained manner.

The book opens with a review of the basic features of neoliberalism. Lilley's introductory essay demonstrates that she has a firm grasp of the basic trajectory of neoliberalism, and she spins the story with uncommon clarity and pith. Indeed, so impressive is her brief review that I now plan to assign it to students to help introduce them to the basic features of neoliberalism.

Like many things, however, the strength of Capital and Its Discontents is also the source of its weaker side. Lilley's incisive lines of query and her theoretically informed interrogations means that the interviewees are generally left expanding upon ideas broached in earlier works. The retorts and rejoinders often directly reference familiar theories and categories. "What I was trying to say" or "as I wrote elsewhere" or "one of my earlier arguments" are locutions encountered frequently, and they underscore the fact that spontaneous dilation is under way. But this also means that the interviews by and large add little new to the critical discussions well under way in other theoretical quarters. Lilley's deft touch renders the interviews interesting, but the very format itself undermines the likelihood that initiated scholars attracted to the book will benefit significantly. The "concept" of the book, in other words, is executed as well as it could be, 
but the fact remains that those readers inclined to read the book are unlikely to derive much substantive theoretical or empirical edification along the way.

And there is another trade-off bound to accompany a work of this sort. The spontaneous form of the obiter sometimes gives the reflections an "off the cuff" sort of feel. This renders some of the responses a bit difficult to follow, and on a couple of occasions which I need not specify, the lines of discussion are anything but clear. We occasionally realize that nothing can replace carefully composed arguments presented in papers, lectures or books.

In one important respect, however, Capital and Its Discontents does make a more original contribution, as doyens ponder the challenges facing the left from their various theoretical positions. We are the better for this. The reflections of David McNally and David Harvey stand out in this respect. Harvey's prescient reflections seem to anticipate the appearance of such movements as Occupy Wall Street. It is worth quoting him at length:

I don't think it's a matter of saying to people, forget your specific struggles and join the universal proletariat in motion; I don't think that's what it's about at all. What we have to do is to find a way of politically uniting those struggles, and that's why I think something like the concept of neoliberalism and its penchant for accumulation by dispossession provide a kind of vocabulary to start to bring together those struggles around a more general kind of theme. So that an Iowa farmer who's just lost his farm can understand how a Mexican peasant feels, can understand how the struggles going on in China are parallel, so we start to see a certain unity in all of the struggles, at the same time as we acknowledge their specificity (59).

And in a similar spirit of practicality and concreteness David McNally remarks that in times of crisis,

people start to raise questions they normally wouldn't raise and even act in ways-like occupying a plant-that they normally wouldn't. On a larger global scale I think we can see it in a whole wave of development. Think of the riots and general strikes in Greece. Or the government in Iceland that fell after agreeing to an IMF package, and after groups in civil society started to organize every Tuesday night outside the Parliament building. Eventually they started to do it every night. There was fighting with the police, there were demonstrations, and eventually the rightwing government in Iceland had to resign (101-102). 
As suggested in the above quotes, Capital and Its Discontents embraces a deeper political principle. It shows us that the dialectical deconstruction of capitalism and its crises by intellectuals is an indispensable element of the left, and at the same time the interviews are infused with the democratic notion that the struggle to overcome capitalism must be broadly based and inclusive. With the spirit of Freud lingering in the background, we on the left suspect that the contradictions at the heart of capitalist social formations, those pressures that supply the very content of politics, inexorably create upheavals and sustained social struggles. And we believe that the intellectual form and political shape we lend to those struggles will be historically decisive. Lilley's sweeping interviews affirm this deeper democratic conviction more than anything else.

McNally, David. 2011. Global Slump: The Economics and Politics of Crisis and Resistance. Oakland: PM Press. ISBN 978-1-60486-332-1. Paperback: 17.95 CAD. Pages: 230.

Reviewed by Bill Burgess, Kwantlen Polytechnic University

David McNally's prognosis in Global Slump seems exactly right:

Rather than describing a single crisis, the term [global slump] is meant to capture a whole period of interconnected crisis - the bursting of the real estate bubble; a wave of bank collapses; a series of sovereign debt crises; relapses into recession - that goes on for years without sustained economic recovery. This, I submit, is what confronts us for many, many years to come (8-9).

My attention was drawn to two points in this book. The first is an important nuance in McNally's discussion of the crisis. The second is his original explanation of the reasons for financialization.

Like most Marxists, McNally roots the current financial crisis in capitalist overaccumulation. The "majority" assumption is that there has been a more or less continuous "bust" in capitalist profits since the 1970s. In contrast, Global Slump insists that our understanding of the current crisis must acknowledge that a genuine profit "boom" occurred between 1982 and 2007. McNally labels this period a "neoliberal expansion" (38). This draws attention to historically-specific factors that are often left out of accounts guilty of the complaint that Marxists have correctly predicted ten of the last 
three great depressions. The emphasis on neoliberalism suggests that rising exploitation may be an important determinant of the crisis. Too many explanations focus one-sidedly on over-investment in machinery.

Attention to rising exploitation also sets the stage for the significance of the "predatory inclusion" (121) of more and more people into financial markets. McNally describes how "sub-prime" mortgages in the US disproportionately targeted poor people of colour. The indebtedness of developing countries quadrupled during the neoliberal boom (127). He emphasizes that credit can offset the dampening effect on consumer demand of rising exploitation. For example, McNally argues that the end of the neoliberal boom was signalled by the 1997 Asian Crisis but massive credit expansion postponed the broader crisis to 2007.

I perceive a partial disconnect between this attention to rising exploitation and ballooning credit and the book's description of over-accumulation in the chapter titled "Manic Depression: Capitalism and its Recurring Crises." The chapter explains that "mechanization is necessary to....win the battle of price competition...as the ratio of labour to total investment declines, so the ratio of profit to total investment will tend to fall" (77-78). The glossary entry for "over-accumulation" reports that it is "caused by intense competition to boost the productiveness of their companies by investing in new plants and technologies" (196).

Readers are directed in a footnote to a forthcoming work which will point out that "the actual process is more complex, with a variety of counter-tendencies. But this explanation does justice to a key part of the dynamics at work" (212). Well yes and no, because as Marx wrote, "to try to explain them [capital's laws] simply as the results of competition therefore means to concede that one does not understand them" (quoted in Lebowitz 2010, 284). McNally (1999) has himself made this point against "horizontal" (inter-firm) accounts of over-accumulation in place of "vertical" (inter-class) accounts. For the fuller, "vertical" explanation I think the chapter needed to include the "problem" of realizing surplus value. This is where rising exploitation and credit nicely fit.

Global Slump identifies the other key element of the neoliberal expansion as the dramatic capitalist expansion in East Asia, especially in China. McNally highlights the dramatic proletarianization of the Chinese peasantry and the massive foreign investment attracted by the precarious position of these urban migrants. "China's working class, today at 750 million... is one and a half times larger than the labour force of all the thirty rich countries of the OECD combined. The country's surplus labour force alone is three times larger than the entire manufacturing workforce of the OECD countries" (52).

It may be that "tendencies towards over-accumulation and declining profitability... have become central features of China's market-driven-development" (57). But the implication seems to be that this process of over-accumulation is the same as in wealthy capitalist countries. How do we then evaluate the influence of the Chinese state on the dynamics of the economy, on investment and demand? The statistic that "China's 
250,000 millionaire households, making up only $0.4 \%$ of the population, now control 70 percent of the country's wealth" (57) caught my eye. I followed the sources to determine that the $70 \%$ actually refers to household wealth, not all wealth. It had been cited for a discussion on social inequality, so it was also my mistake to have read it too literally with other issues in mind. But my point about this experience is the need for more clarity on the particular structure and dynamics of an economy so central to global capitalism.

The second main point I got from Global Slump is McNally's explanation of financialization. The numbers are always impressive. Financial returns in the US rose from $16 \%$ of total profits in 1973 to $41 \%$ in 2007 (86). Trading in foreign currencies increased from twice the value of trade in goods to 70 times by 1995. "Over-the-counter" trade in derivatives grew from \$1.2 trillion in 1992 to $\$ 4.2$ trillion in 2007 (94). McNally provides a clear, understandable description of the various and often esoteric financial instruments - derivatives, collateralized debt obligations, credit-default swaps and the like.

He then briefly outlines a distinctive theory about the origins of financialization. It emphasizes the "historic transformation of world money that occurred after 1971, when the US government ended the convertibility of dollars for gold" (10). With no relatively stable reference point for value, the need arose for insurance-like protection against the resulting fluctuation in currencies and interest rates in the context of globalized production and sales. Thus, financialization does not flow from opportunities created by deregulation. It is rooted in the objective need of globalized capitalism for a measurable standard of value. McNally does not discuss it in these terms, but this sounds like an orthodox Marxist theory of money that had been challenged by the end of the gold standard.

In addition to trying to clarify the nature of the crisis, Global Slump was written to "think through what all this means for movements of resistance, struggles for social justice, and anticapitalist politics" (ix). In his second-last chapter McNally tries to "chart pathways of resistance and anticapitalist transformation" (10) by reviewing recent movements to occupy factories, general strikes in Guadeloupe and Martinique, social uprisings in Bolivia and Oaxaca and mobilizations of immigrants in the US. He emphasizes that the anticapitalist Left must "reclaim democracy - radical, direct democracy in particular - as a core value" (189).

McNally's review of the contours of resistance from below depicts the commonality of struggles against neoliberal capitalism in imperialist and imperialized countries. Some of us would distinguish the context of these struggles more than he apparently considers necessary. For example, the issue of anti-imperialism is not developed in his account of the "mass anti-neoliberal upsurges [that] toppled governments and rolled back privatizations in countries like Bolivia, Ecuador and Venezuela" (152). The discussion of anti-neoliberalism and anti-capitalism leaves out the governments placed in power by the above upsurges, and projects like the Bolivarian 
Alliance for the Americas (ALBA) and the Universal Declaration of the Rights of Mother Earth.

This is an important book to read, especially for its distinctive explanation of the economic crisis.

\section{References}

Lebowitz, Michael A. 2009. Following Marx: Method, Critique and Crisis. Boston: Brill

McNally, David. 1999. "Turbulence in the World Economy." Monthly Review 51, no. 2. http://monthlyreview.org/1999/06/01/turbulence-in-the-world-economy

McBride, Stephen and Heather Whiteside. 2011. Private Affluence, Public Austerity: Economic Crisis and Democratic Malaise in Canada. Halifax: Fernwood Publishing. ISBN 978-1-55266-403-2. Paperback: 24.95 CAD. Pages: 153.

Reviewed by Joan McFarland

St. Thomas University

Stephen McBride and Heather Whiteside's new book, Private Affluence, Public Austerity, is a remarkably detailed and insightful analysis - truly a tour de force. It examines the causes and consequences of neoliberalism in Canada with particular attention to, and exploration of, the role of not only three recent economic crises but also a political crisis or "democratic malaise." There is a powerful message to the book. Although "crisis-prone," neoliberalism has proven to be amazingly resilient to crisis. Thus, it seems that it will take more than just crises to bring about an end to neoliberalism and its replacement with an alternative paradigm.

Private Affluence, Public Austerity examines the establishment of a neoliberal regime in Canada and analyzes the nature of that regime in the context of the recent financial crisis and two preceding economic crises as well as an on-going political crisis. In short, although the economic crises have, to a large extent, been caused by neoliberalism, neoliberalism has proven itself to be resilient and been retrenched rather than abandoned in their wake. In terms of the political crisis, the book explores what it 
calls a "democratic malaise" suggesting that the latter can be explained by economic and social inequalities and the shutting out of possibilities for public input into policy decision-making, both factors having been exacerbated by the neoliberal regime.

The book begins with a discussion of the financial crisis beginning in 2007 which then frames the rest of the analysis. In the second chapter, various "long-wave" theories of capitalist crises are examined. This is followed by discussions in the third and fourth chapters of the Keynesian welfare state and the neoliberal state. The latter is characterized, on the one hand, by "private affluence" as a result of the privileging of the market but, on the other hand, by "public austerity" as a result of the policies pursued under neoliberalism. These two chapters, Chapters 3 and 4, contain a very thorough and useful analysis which, we are told in a footnote, has been revised and updated from chapters in McBride's Paradigm Shift: Globalization and the Canadian State (Fernwood, 2001 and 2005). Chapter 5 provides a detailed look at the three crises of the neoliberal period in Canada: the recession in the 1980s, the recession in the 1990s, and the global financial meltdown of 2007-09. Chapter 6 moves to a discussion of the connection between neoliberalism and the "democratic malaise" of the voting public. The concluding chapter considers the legacy and the future of neoliberalism and what the "conditions for change" might be. The discussion also considers such questions as the impact of, and future for, Keynesian stimulation policy and the significance of some new crises which have emerged - the sovereign debt crises of 2010 onward, most notably in Greece.

McBride and Whiteside describe their theoretical framework as being in the tradition of critical political economy (20). In their chapter, "Theories of Capitalist Crises," they begin by showing the inadequacy of neoclassical economic theory which denies the possibility of crisis by claiming an automatic readjustment of the system to any disturbances. Instead of accepting this approach, McBride and Whiteside look at various "long wave" (i.e. of 40-60 years duration) crisis theories. These include the social structure of accumulation (SSA), as theorized by Phillip O'Hara among others, in which institutional innovations guide strong growth in the upswing of a long wave but these same institutional innovations eventually break down and "generate their own unique contradictions" in the downswing (21). Regulation theory, pioneered by Michael Aglietta, includes an analysis of institutions as does SSA but adds to it a "regime of accumulation" approach. Under regulation theory, the mid-70s crisis is seen as a crisis of the Fordist regime of accumulation. The authors also present David Harvey's Marxist overaccumulation explanation of crisis as rooted in capitalist production and the contradictions it produces as accumulation proceeds - namely a lack of markets and of opportunities for profit-making.

In addition to the above approaches, the authors use a "paradigm approach," influenced by Peter Hall, which they locate within the broader set of relations, in terms of institutions as in SSA, or in capitalism as an economic system as in overaccumulation theory (33). Using the "paradigm approach," they examine the Keynesian and neoliberal 
paradigms as well as the "paradigm shift" from one to the other and conclude that there are inherent contradictions in neoliberalism itself which bring about crises.

The analysis of the relation of the economic crises to neoliberalism starts with the identification and description of three crises experienced in Canada in the neoliberal era. The first two, which took place in the 1980s and 1990s, were characterized by recessions with low growth and high unemployment. The third crisis, in 2007-09, began with a financial meltdown and moved into an official recession with negative growth rates of real GDP in the last quarter of 2008 and the first two quarters of 2009. The authors argue that these crises were the outcome of contradictions not only of capitalism but of neoliberalism itself. In the 1970s, there was a decline in profits for capital explained by Harvey, for example, in terms of overaccumulation and the reduced possibility of profitable investment. However, in addition, the neoliberal policy response to stagflation in the 1970s of high interest rates and cuts to social spending induced recession and in so doing created its own contradictions. Further, they argue that the bailouts to the 2007-09 financial crisis have created the need for further public austerity, another contradiction of the neoliberal policy regime.

But not only are the crises brought about by the contradictions within capitalism and neoliberalism, but neoliberalism so far has shown resilience in the face of these crises - leading even to retrenchment or "rejuvenation" as some authors have termed it (91). McBride and Whiteside, following the language of Jamie Peck and Adam Tickell, describe not only the "rolling back" of the Keynesian SSA during the crisis of the 1980s but also a "rolling out" of further neoliberal institutions of a neoliberal SSA during the crisis of the 1990s (89). During the financial crisis of 2007-09, in desperation, the neoliberal regimes used some Keynesian-style stimulus spending. However, McBride and Whiteside judge such stimulation to have been "temporary and shallow" (6). Further, the stimulus spending, in the end, led to the perceived need, within the neoliberal policy framework, for a return to austerity to pay for it.

The analysis of Private Affluence, Public Austerity ends with an examination of a political crisis or "democratic malaise" which the authors argue has itself been induced by further contradictions of neoliberalism. Much has been written of the democratic decline and apathetic citizenry during recent years in Canada and North America generally. The symptoms are low voter turnout, lack of trust in democratic institutions and a lack of knowledge about the constitutional system. The authors survey some of the explanations that have been offered for this. All are at the level of the individual and their participation or not in the political process. However, McBride and Whiteside, instead of focusing on the attitudes and psychology of the individual, argue that it is neoliberalism itself and "the inequalities that it generates" (95) which offer the best explanation of the democratic malaise. If, under neoliberalism, even parliament loses decision-making power as is argued earlier in the book (72), members of the citizenry have good reason to believe that 
they have virtually no say in any public decision-making and thus a quite rational excuse for non-participation in the political process (98).

In the final chapter, the authors suggest that, in order to create a new paradigm, an overcoming of the "democratic malaise" will be needed. Further, to move beyond neoliberalism, the creation/framing of an alternative paradigm to neoliberalism needs to be a major priority and needs to begin now.

Harvey, David. 2010. The Enigma of Capital and the Crises of Capitalism. New York: Oxford University Press. ISBN 978-0-19975-871-5. Cloth: 27.95 CAD. Pages: 296.

Reviewed by Matthew Brett

Concordia University

A seeming deluge of radical literature continues to emerge in response to the latest crisis of capitalism. David Harvey's The Enigma of Capital offers a unique and compelling theoretical contribution to this growing body of literature. While Enigma finds its strength primarily as a theoretical text, the theoretical constructs are developed in a clear and accessible manner. This poses something of a trade-off, insofar as Harvey runs the risk of abandoning the conceptual rigour of classical Marxism in order to make its general ideas more accessible. Enigma is nevertheless one of the most dynamic recent theoretical constructs developed with which to understand and confront capitalism today.

Enigma can reasonably be situated within Harvey's broader Marx project, a lifetime effort to make the works and ideas of Karl Marx relevant for a contemporary audience. The Marx project includes a series of online audio-video lectures thus far covering Volumes 1 and 2 of Capital. Harvey has also deliberately shifted away from the conceptual rigour of his earlier work, with Limits to Capital (1982) serving as a benchmark of theoretical density. Enigma simplifies away the often torturous conceptual apparatus that Marx constructed in favour of plain language. In this respect, Enigma would be an ideal text for anyone searching for an accessible theoretical understanding of the latest crisis and the nature of capital flow.

Like many books on the latest crisis, Enigma begins with a brief overview of the roots and consequences of the Great Recession. The central thesis of this chapter is that capitalism has become increasingly unstable since its neoliberal turn in the 1970s. This increasing volatility stems from capital's inherent drive toward growth and expansion. This need to constantly grow presents the system with a "capital surplus absorption 
problem," in which profits generated must be reinvested again in order for the system to grow (28). Since the 1970s, this absorption problem has been resolved through an increasing reliance on high finance. The financialization of capitalism has spurred extreme volatility in the global economy, and it was only a matter of time before the bubble burst.

Harvey then shifts to developing a nuanced theoretical apparatus to make sense of it all. Capital is a process that must necessarily grow and circulate in order to survive. "Continuity of flow in the circulation of capital is very important. The process cannot be interrupted without incurring losses" (41). There is also a continual drive to speed up this circulation process, which necessarily entails reducing spatial barriers in the physical environment; innovations in transport and communications are therefore critical (42). There are nevertheless six potential barriers or blockage points to this accumulation process that must be overcome in order for capital to reproduce itself and grow. These barriers include: (i) insufficient money capital; (ii) scarcities or difficulties with the labour supply; (iii) inadequate means of production and natural limits; (iv) inappropriate technologies and organizational forms; (v) resistance or inefficacies in the labour process; (vi) lack of demand backed by money to pay in the market. Blockage at any one of these points can disrupt capital flows and potentially lead to crisis. Chapters 3 and 4 then deal with each of these potential barriers in detail, offering clear and easy-to-understand examples.

Chapter 5 shifts to developing an additional theoretical apparatus which overlays these potential barriers and blockage points. Harvey argues that capital must revolve through seven inter-related yet distinctive "activity spheres" in search for profit. These spheres include: technologies and organizational forms; social relations; institutional arrangements; production and labour processes; relations to nature; the reproduction of daily life and the human species; and "mental conceptions of the world" (123). Again, clear examples are provided as a means of illustrating how these activity spheres operate in practice. While these theoretical constructs may sound complex, Harvey presents these ideas patiently and in a very accessible manner. It is also worth noting that this theoretical construct stems entirely from a passing footnote in Chapter 14 of Capital (Vol. 1). This footnote captures Marx's dialectical method of thinking, which Harvey then builds upon to develop a fairly unique theoretical apparatus.

The book closes with an invigorating chapter on the struggle for an anti-capitalist transition. The blockage points and activity spheres developed in the preceding chapters are turned on their head, to be utilized for anti-capitalist ends. Harvey argues that "capitalism will never fall on its own. It will have to be pushed. The accumulation of capital will never cease. It will have to be stopped. The capitalist class will never willingly surrender its power. It will have to be dispossessed" (260). Harvey then sketches a revolutionary outline of how this dispossession can be achieved. Political organizing and thinking must work across all seven activity spheres in order to foster an anti-capitalist 
transition. Relations to nature and to each other must be reconfigured; daily life habits must evolve along anti-capitalist lines; modes of production must be controlled by workers and communities; mental conceptions of the world must shift away from neoliberal ideology toward something entirely new. In this chapter, Harvey is seeking nothing less than a full-scale transformation of the dominant social order.

This closing chapter on anti-capitalist struggle has drawn its fair share of criticism. Some activists argue that his approach is already being implemented; anarchists may challenge his view that autonomist organizing is unable to develop large-scale organizational forms; others may argue that he downplays the role of race, gender and difference. Harvey's reference to violence may also draw criticism. These are all interesting criticisms worthy of pursuit and reasoned deliberation.

To this series of critiques, it is worth raising a level of concern over Harvey's drift away from classical conceptual rigour. On the one hand, removing Marx's dense conceptual baggage makes his ideas accessible and relevant. Enigma is receiving widespread attention precisely because Harvey has simplified classical Marxist concepts and theories. This is encouraging, insofar as the anti-capitalist ideas of Enigma will reach a broader audience than much of the Marxist literature currently available. On the other hand, removing classical language and concepts runs the risk of losing the theoretical roots of anti-capitalist theory and action. This is a fine balance. For example, Harvey never makes explicit reference to human labour as being the source for value in capitalist economies. This is problematic when adopting a Marxist framework of analysis.

Nevertheless, Harvey offers one of the most novel and accessible explanations of capitalism today. There is an element of dark humour in this as well: his novel theoretical constructs are based largely upon a passing footnote that Marx published over 140 years ago. Enigma offers both a method for understanding the world, and a course of action for changing it along anti-capitalist lines. Both contributions are welcome and, indeed, necessary.

Olsen, Gregg M. 2011. Power and Inequality: A Comparative Introduction. Don Mills: Oxford University Press. ISBN 978-0-19-544400-1. Paperback: 24.95 CAD. Pages: 216.

Reviewed by Larry Patriquin

Nipissing University

A book on inequality could not be more timely, when movements to occupy financial and other business heartlands have broken out in many countries, when even 
the staunchly pro-capitalist OECD has pointed to the dangers of societies pulling apart socially and economically, and when some of the wealthiest people on the planet, like the billionaire Warren Buffet, are practically begging governments to increase their taxes.

Power and Inequality can be described as a more-or-less textbook, though thankfully Olsen does not present his information in a "neutral," "he said, she said" narrative, typical of such books. He is clear from the beginning that social inequality "is created, reproduced, institutionalized, legitimated, and perpetuated by the people who hold the most resources in society" (8). The book is divided into three parts of roughly equal length, with each part containing two chapters: Part I: Considering Inequality, has an introduction (Ch. 1) and an examination of four basic models of equality (intrinsic, opportunity, condition, outcome) (Ch. 2); Part II: Measuring Inequality, surveys material indicators of inequality (poverty, income, wealth, and life chances) (Ch. 3) alongside nonmaterial indicators, in particular rights and entitlements (Ch. 4); and Part III: Explaining Inequality, covers theories that justify inequality (sociobiology, functionalism, and culturalist accounts) (Ch. 5) and those opposed to inequality, especially theories that focus on power and conflict (Ch. 6). The book is structured around comparisons within and between three highly unequal Anglo-Saxon countries (Great Britain, Canada and the United States) and three more egalitarian - though still unequal - Nordic nations (Finland, Norway and Sweden).

For some, there will be a sense of déjà vu in reading this work. Chapters 1, 5, 6, and to some extent 3, go over ground that was well-covered in Olsen's previous, superb book, The Politics of the Welfare State (Oxford University Press, 2002). As a consequence, for those familiar with The Politics, chapters 2 and 4 in Power and Inequality will contain most of the fresh material. The second chapter, the best of the lot, is an important overview, given that most discussions of equality are marred by superficial notions, prevalent among far too many students, that equality means we must all be the same have the same incomes, wear the same clothes, even think the same thoughts. The fourth chapter is also quite informative, focusing on human rights and entitlements to income, services and protective legislation (for example, workplace health and safety). While worth consulting, the book will be of more limited use to academics, which is not surprising given that it is an introductory text. However, for students approaching the topic of inequality in depth for the first time in upper-year undergraduate courses, this work will give them a solid grounding in the key issues and debates.

My comments in the rest of this review are directed at the improvements that could be made to a second edition. First, while Power and Inequality is a relatively short book, it could be even shorter. Most of the more than 20 pages of discursive notes, which appear at the end of the chapters, could be left on the cutting-room floor. The section titled "The Organization of This Book" (9-13) also could be dispensed with. (By the way, every publisher should have as a cardinal rule: "Book proposals must never reappear in 
the introduction of the book.") The section "The Comparative Approach" (26-30) could be condensed to a paragraph or two, while the "Early Statements" (on inequality) (13943) could be excised as well; the quick tour of Plato, Aristotle, Hobbes, Locke, Rousseau and Adam Smith is too sketchy to be useful.

Second, the book embodies one of my pet peeves, namely that some of the data used were getting a tad moldy from the moment of publication. I would have expected a work appearing in 2011 (released in October 2010) to have had more up-to-date statistics. With the exception of Table 6.1, on union density, which goes down to 2007, most of the other tables end around 2004, with one (\#3.3) on wealth inequality ending in 2002 and one (\#4.3) on public social expenditure as a percentage of GDP ending in 2001. Granted, it often takes a few years for data to become available, but the statistics in most of these tables probably could have been brought closer to the date of publication, hence helping to lengthen the shelf-life of the book.

Third, there is an important gap in the discussion of the theories that legitimate inequality (Ch. 5). While it was important to analyze these theories to some extent, most of them strike me as "old hat." For sure, these arguments, in particular racist aspects of social Darwinism, are always lurking somewhere in the shadows. It seems to me, however, that the dominant defense of inequality these days is an economic one, namely that without fabulously wealthy people in our society - the "job creators" - the rest of us would be stumbling around like kittens whose eyes haven't yet opened, helpless creatures incapable of organizing their economies. There is some hint of this "economic" discussion (see 94-6), but the pro-capitalist defense of inequality should be given much greater attention. Olsen could challenge the myths that equality produces economic stagnation, harms innovation, reduces productivity, rewards the lazy, crushes individualism, removes incentives for obtaining a post-secondary education, and so forth. Most conservatives, at least those running for public office, would not use the theories highlighted by Olsen to defend their position, and I suspect that today few, even of their ilk, would strongly espouse these theories.

Finally, the book ends with "Challenging Inequality" (Ch. 6), which focuses mostly on Marx, Weber and "power resources theory." This concluding account should be expanded to also articulate the socio-economic advantages of egalitarianism and perhaps give suggestions of how we might get closer to a more equal society. It is especially important to demonstrate to students, a majority of whom do not bother to vote, the importance of old-fashioned political activity (in the form of elections, parties and so on) in tackling the inequalities that so many of them find repugnant. 
Livingstone, David; Dorothy Smith and Warren Smith. 2011. Manufacturing Meltdown: Reshaping Steel Work. Halifax: Fernwood. ISBN 978-1-55266-402-5 Paperback: 27.95 CAD. Pages: 218.

Reviewed by Ann Duffy

Brock University

Livingstone, Smith and Smith provide us with an invaluable guide to understanding the specifics of the decline of steel industry in Hamilton and, more broadly, the implications of recent momentous shifts in Canadian labour markets for workers, their families and communities. Livingstone's introduction raises the increasingly ubiquitous question of whether there is a future for manufacturing employment in developed nations. Livingstone argues for the possibility of a profoundly changed but persevering steel industry. These themes of transformations and potentialities permeate the subsequent essays.

The first chapter, by Livingstone, guides the reader through the tumultuous history of Stelco in the context of a globally transforming steel industry. This very detailed discussion introduces most of the major economic factors in play. Technological innovation, global competition, trade agreements, unions, finance capital and workplace restructuring all figure prominently. In an account with Shakespearian overtones, Stelco rises to become the largest Canadian-owned industrial company and for sixty years is Canada's "wealthiest, largest and most diversified steelmaker." By 1980, with 26,000 workers, it is the cornerstone of Hamilton's economy. From these heady heights, the decline is precipitous. Thousands of workers are displaced and by 2003 about 9,000 workers remain. These numbers dwindle to a mere 850 by mid-2010. As Livingstone explains through interview excerpts, these events transform the lives of workers, their families and the surrounding community. A "good job for life" is beyond the grasp of all but a few and many bustling plant floors become "human deserts."

Against this historical backdrop, in Chapter 2 Dorothy Smith and Stephen Dobson explore the implications of these events for training and skill retention at Stelco and, more generally, in the manufacturing sector. As the authors explain, former patterns of skill transmission tended to rely on worker-controlled on-the-job learning, apprenticeships and transmittal of skills in the working-class community. The net result was a workplace that valued the experienced worker's expertise and which tended to draw managers and supervisors from the shop floor. The restructuring of the steel industry has eviscerated these processes and replaced them with state-funded educational programs, notably at community colleges, that target corporate needs. The authors underscore the importance of recognizing the knowledge and skills (and workers' control) that are being lost. As Stelco's labour force ages (reflecting seniority rights and layoff patterns), there are few mechanisms for capturing the worker expertise developed from years of on-the-job 
experience. In the more generalized process, the manual/mechanical skills "stored and transmitted" in working-class communities are being steadily undermined and workers' power resources eroded.

In the final chapter by David Livingstone and Warren Smith (a long-time Stelco steelworker and former president of USW local 1005) the Stelco story is updated. In 2004 the company declares bankruptcy and in 2007 US Steel takes over. On the ropes in the face of cheap imported steel and mounting debts, Stelco still fails to address the problem of labour force renewal. As its workforce ages and retires, it relies on overtime and contracting out (including the rehiring of retirees on a contract/temporary basis) to manage its labour needs rather than hiring and training a younger workforce. At the same time, including under US Steel, the company maintains a heavy-handed, top-down approach to labour relations which excludes the kinds of management-worker consultation which might facilitate co-operation and on-the-job training. The authors conclude with an examination of alternative futures for Stelco/US Steel. In particular, they focus on the undesirability of foreign ownership and the possibilities for repurchase by Canadian private capital, for the creation of a Crown Corporation and for worker ownership. In terms of possible alternatives for management-labour relations, they critique top-down hierarchical management and urge consideration of consultative management, industrial democracy and worker self-management. Emphasizing the possibilities implied by agency and political will, they conclude with the potentialities for a more democratic and environmentally friendly workplace and economy.

There is no question that this collection provides invaluable insight into the processes that transformed Stelco, Hamilton and, in many respects, the Canadian economy and working-class communities. The analysis is accessible and compelling. Further, the reader is invited to "make connections" to a wide array of issues beyond the factory floor, including the role of education and training, changes in working-class communities and families and the prospects for democratic actions in Canada.

Within this overall very favourable response, I would suggest that the argument that manufacturing will persist as a significant source of employment warrants, in my view, a bit more qualification. The sheer numbers of lost jobs speaks to a profound shift not only in manufacturing employment but also for the communities which rely on these jobs. The process of "making things to sell" may persist, but "good" manufacturing jobs (secure, unionized, well-paid and well-benefited employment) appear decidedly imperilled. Ironically, in the absence of much else in the way of employment, arts and crafts are being promoted by local governments and agencies in Hamilton as the new entry point into the labour market. As de-industrialized workers I've interviewed in Niagara repeatedly comment, "we need good jobs" and "we need thousands of jobs, not hundreds." And, as those workers who have been "adjusted" into both service sector work and low-paid manufacturing work complain, "how is it possible to have a mortgage on $\$ 15$ an hour?" 
The current economic downturn has provided a further opportunity for companies to shed more unionized workers or to hamstring unions with tiered contracts and the constant threat of layoffs. In this context, it appears likely that only a minority of workers will have continued access to the traditional "good" manufacturing job while the overwhelming majority will be displaced to service sector employment or to a kind of marginalized manufacturing work characterized by much smaller workplaces, little or no unionization and insecure employment. These smaller manufacturing plants are clearly more vulnerable to relocation to cheaper labour markets. In the growing absence of good unionized jobs secured by a massive workforce, the working class and its communities will in all likelihood be fundamentally altered.

Dorothy Smith and Stephen Dobson have raised an important issue in terms of the erosion of working-class skill sets-skill sets that traditionally grounded familial and community relations and were an important source of self-worth. Hopefully, researchers will pick up on this important cross-over between paid and unpaid work and community and explore its connections to both commodification and the rise of corporations such as Home Depot.

Finally, although the proposed alternative futures are desirable, they seem far removed. Recent events, such as the decision to dismantle the Canadian Wheat Board, the lack of an effective, co-ordinated reaction to US Steel, the almost complete absence of effective responses from any level of government to the closure of industries, the blatant bullying by Caterpillar Corporation and, overall, the growing gap between haves and have-nots suggest a troubled path to progressive social change.

Camfield, David. 2011. Canadian Labour in Crisis: Reinventing the Workers' Movement. Halifax: Fernwood. ISBN 978-1-55266-416-2. Paperback: 19.95 CAD. Pages: 160.

Reviewed by Stephanie Ross

York University

In Canadian Labour in Crisis, David Camfield offers a bracingly honest and accessible look at the labour movement's current impasse. Grounded in the conviction that working people's movements are central to greater social and economic equality and the development of human capacities beyond that envisioned by profit-driven capitalism, Camfield argues that union renewal, the "attempt to energize the movement in its current form" is not enough. Rather, "sweeping changes that would reinvent the movement" are called for (6-7). Combining overviews of academic literature and political commentary 
with interviews with movement leaders, staff and activists - impressive for such a short volume - Camfield gives voice to many labour activists' frustrations with unions' inability to halt a long-term process of decay. He also seeks to articulate the means of the movement's reinvention.

Camfield goes beyond the union renewal literature's typical empirical indicators sinking or stagnant union density or organizing rates - and provides an unflinchingly comprehensive (if dismal) picture of union decline. The union movement is revealed to be a very sick patient indeed. In the workplace, unions' bargaining power has been diminished. Although the "union advantage" - the premium in wages and benefits union members earn compared to their non-union counterparts - has been maintained, it has actually become a source of resentment for many workers outside union structures. The decline in unions' economic power and public esteem combine to make organizing new members exceedingly difficult. Instead, unions frequently pursue already-organized union members, whether through mergers or inter-union competitions, to cope with membership (and hence financial) crises. In the political sphere, despite much energy put into lobbying and electoral mobilization of various kinds, unions' influence over policy decisions has waned, even where labour-friendly governments are in power. Other forms of extra-parliamentary political action are also on the decline. Add to this the atrophy of internal democratic life, a crisis in membership participation, and the narrowing of debate and contestation within unions, which makes the search for effective solutions all the more difficult.

Camfield's diagnosis of this breakdown in unions' capacities for resistance and socio-economic transformation has five elements, a complex of unfavourable external conditions and the consequences of choices made in both the past and the present. First, beginning in the 1940s, an exceedingly narrow conception of unions' mandate, constituency and strategic toolkit was institutionalized in both law and union practice, marginalizing other modes of worker self-organization and the potentials they carried. Second, the broader social and cultural supports for vibrant, politically informed, pluralistic and solidaristic working-class communities have eroded. Third, radical changes wrought by the neoliberal restructuring of late $20^{\text {th }}$ century capitalist accumulation and state regulation severely undermined the material basis of $20^{\text {th }}$ century union forms. Fourth, left organizations outside the unions, both socialist and social democratic, have also weakened since the 1970s, no longer able to organize internal union opposition or sustain inter-union activist networks. Finally, union leaders have made poor choices at crucial moments when responding to these negative political-economic conditions. Many union leaders and staff remain "doggedly loyal" (85) to bureaucratic "responsible unionism", have opted to contain resistance where it has emerged, and thus have exacerbated the above problems and accelerated the process of decay.

Given the depth of these problems, Camfield rightly argues that revitalizing existing (deeply flawed) union practices, is insufficient. Initiatives of "reform from above" 
simply reinforce rather than challenge the underlying causes of the movement's problems. Instead, the movement's reinvention will require initiatives "from below" to turn it in a more democratic, militant and radical direction. Camfield reviews what he terms "seeds of hope": concrete practices evident in various parts of the workers' movement - both inside and outside unions - that, if expanded and generalized, could form the basis of such a reinvention. He emphasizes initiatives that aim to deepen union democracy and support the emergence of member-activists who not only more truly reflect the diversity of the working class but are also capable of undertaking organizing initiatives independent of unions' leaders and staff. Ultimately, Camfield argues that unions must adopt a commitment to mobilize and organize the entire working class, not only its unionized elements, to fight in all the arenas that shape working-class life, not just the workplace, and to generate an anti-capitalist and anti-oppression working-class politics.

Despite the powerful analysis of the movement's problems and necessary solutions, there are contradictions, particularly over how the capacities for such thoroughgoing change are to be generated. One of the book's strengths is its use of Richard Hyman's nuanced understanding of bureaucracy as a set of social relations of dependence on expertise, the pedagogical effects of which are felt by both leaders and members, who internalize bureaucracy as common sense. This usefully moves us away from simplistic nostrums that leaders are always to blame for every misstep or "betrayal" and helps us understand the systemic reproduction of union habits. However, members are seen as the source of radical transformation, though they are no less bound up in bureaucratic mentalities than leaders. Many members share with their leadership counterparts a vested interest in the status quo of union life. Their economic insecurity also undermines their willingness to resist. A union activist quoted here indicates that "a lot of people don't want to cause waves in the workplace so they don't enforce the collective agreement" (10). If that's so, why should we expect members to be more willing to engage in direct action, a more confrontational act than filing a grievance? The prescription of "reform from below" does not fully explore the conditions needed for members' confidence to be regenerated, and the role that progressive union leaders with access to resources will have to play in that process.

Similarly, it isn't clear what kinds of structures are necessary to rebuild workingclass power. There is an implicit preference for localism here, even though Camfield acknowledges some of its limitations. For instance, he decries the way collective bargaining structures fragment workers' power, and yet mega-locals, which were created (at least in part) to address such fragmentation, are "beyond hope of democratization" (61). The decline of pattern bargaining is seen as part of the roots of unions' problems, yet Camfield calls for local autonomy and members' democratic control over bargaining. There is an unresolved tension here between the scale of workers' power and the conditions that allow for members' meaningful democratic control. Undoubtedly, most 
collective bargaining processes should be significantly democratized, but this is no simple matter. Indeed, local autonomy framed as "democracy" often reinforces fragmenting dynamics as members retain control over their bargaining agenda in their workplace, and refuse obligations to broader collective identities and interests. What then is the way forward? The book could have paid greater attention to such difficulties.

Despite these caveats, this book is required reading for working-class activists throughout the movement. Every union education department should adopt Canadian Labour in Crisis for immediate reading by their own leadership and activist cadres. Many will find the content uncomfortable, as it challenges deeply held assumptions on which lifetimes of activism have been based. And yet, as attacks on the remnants of workingclass power continue to mount, this book will spark a necessary debate over what the labour movement must do to remain a relevant force for social transformation.

Webber, Jeffrey. 2011. From Rebellion to Reform in Bolivia. Chicago: Haymarket Books. ISBN: 978-1-60846-106-6. Paperback: 21.50 CAD. Pages: 281.

Reviewed by Manuel Larrabure York University

For those on the left, it has become common sense to think of the current governments in Venezuela, Bolivia, Ecuador and sometimes even those in Brazil and Argentina as presenting alternatives to neoliberalism, and perhaps even capitalism itself. To some degree, this is understandable. Many of these countries witnessed impressive mass popular movements and uprisings that articulated a significant challenge to neoliberalism in the region. These included the 1989 Venezuelan uprising known as "el Caracazo," the Argentine uprisings in 2001-2002, and the water and gas wars in Bolivia between 2000 and 2005. In all of these cases, new governments promising a break with neoliberalism were elected into office, and in Bolivia and Venezuela the phrase "socialism for the $21^{\text {st }}$-century" would soon enter everyday discourse.

However, more than a decade into Latin America's "pink tide," is it still possible to characterize the governments of Hugo Chavez, Evo Morales and others as presenting a challenge to neoliberalism or capitalism? Was it ever correct to depict these governments in such a manner? Addressing the case of Bolivia specifically, Jeff Webber answers these questions with a resounding and controversial no. Webber's central argument is that the Morales government is pursuing an agenda of "reconstituted neoliberalism," betraying many of the demands and aspirations of the popular movements that elected the MAS 
(Movimiento al Socialismo or Movement Towards Socialism) into office. Challenging widespread interpretations of contemporary Bolivian politics, Webber's narrative depicts the popular insurgencies between 2000 and 2005 as constituting a "revolutionary epoch" that fell short of a full social revolution. The lack of a full socialist rupture in the country Webber attributes to the absence of a revolutionary party capable of articulating itself at the national level. Consequently, it was the MAS that became the only political instrument capable of articulating a national program.

Although, at first, the MAS maintained important links to popular movements, by 2002, Webber argues, it began to court the votes of the urban middle classes in an attempt to secure an eventual electoral victory. Originally conceived as a political instrument rooted in indigenous social movements rather than a political party, this was a crucial turning point for the MAS. Top layers of the MAS became filled with middle-class intellectuals and the party quickly moved away from street militancy. This shift became most evident during the gas wars in which the MAS prioritized elite negotiations over mass mobilization. The party's shift to a focus on electoral politics paid off in 2005 with the historic election of Evo Morales to the presidency. However, by this point the MAS, Webber explains, had already steered away from a revolutionary program.

This shift in the MAS became evident as the party, following the ideas formulated by Vice President García Linera, began to pursue the development of "AndeanAmazonian capitalism" in Bolivia, with a transition to socialism to be delayed for 50 to 100 years. In the meantime, the MAS would apply a neo-structuralist developmental model that did away with some neoliberal orthodoxies but retained a belief in the market as the central organizing principle in society. Webber strongly criticizes this "stagist" approach, arguing that it artificially disaggregates indigenous liberation and social transformation, and ignores the relatively favorable regional and global balance of forces Bolivia currently finds itself in. Another crucial aspect of the MAS's program, Webber argues, was the adoption of a conciliatory position towards right-wing demands. This was most obvious in the MAS's dismissal of a radical constituent assembly, as proposed by a variety of social movements, opting instead for a constituent assembly that would include the right wing opposition. Crucially, as Webber explains, this allowed the right wing to slowly re-articulate itself over time and eventually develop an aggressive autonomist agenda in the "media luna" region of the country.

Having outlined the MAS's origins and rise to power, Webber proceeds to assess its record since taking office, providing compelling evidence that the party adheres to a program of "reconstituted neoliberalism." First, he notes that for most of its first four years in power, the party pursued a program of high growth and low spending. Consequently, poverty and inequality remained largely unchanged. In addition, the MAS pursued an agenda of labor flexibility that intensified the labor process and therefore increased the rate of exploitation, as well as added to working-class fragmentation. At the political level, Webber continues, the MAS failed to adequately support the demands of 
workers and communities at a number of crucial moments, including the 2008-2009 Colquiri mining conflict and the 2010 strikes led by the Bolivian Workers' Central. On this latter occasion, Morales himself proceeded to demonize the protests by suggesting sectors of labor had been infiltrated by the right wing. Later, the government successfully divided the workers by accusing some of being ultra left Trotskyites.

The evidence Webber presents is certainly compelling. However, there are a number of conceptual and empirical points that should be debated further. First off, although relatively low levels of social spending do cast serious doubts as to the MAS's commitment to a transformative project, looking at the quality of existing social spending would also be helpful when making this assessment. Webber does not fully examine whether there has been any changes on this front. A more contentious point is that Webber seems to adhere to an instrumentalist view of the state, that is, the view that the capitalist state only works for the interests of the ruling class. Hence, for him, revolutions must come from social movements working from the "outside." Not surprisingly, Webber is therefore deeply suspicious of the MAS, sometimes coming close to a one-sided analysis of events.

For example, according to Webber, the 2008 recall referendum, in which two right-wing prefects lost their positions, was ultimately more helpful to the right wing, allowing it to acquire legal legitimacy for its autonomist project. However, looking at the state as the articulation of class forces (albeit always tilted in favor of capital) might lead one to interpret this event as expressing class contradictions within the state. Hence the outcome of the recall referendum could be seen as expressing both the interests of capital and at least some of those held by Bolivian workers and indigenous movements. In addition, can we really think of social movements as ever existing totally outside of the state? If not, what does it mean to work from the outside? Finally, Webber's argument that the lack of a full social revolution in Bolivia between 2000 and 2005 was due to the lack of a revolutionary party needs further explanation. If, in its early years, the MAS, with its strong roots to workers and indigenous social movements, was not a revolutionary party, then what would a revolutionary party look like?

Notwithstanding the above questions and comments, Webber's book provides a badly needed corrective to the uncritical and celebratory views often presented about Evo Morales and the MAS, and their role in contemporary Bolivian politics. It is also a courageous and principled defense of Bolivian workers and communities engaged in class struggle on the ground, whether against transnational corporations or the MAS. This book therefore demands that we rethink our common sense assumptions about Bolivia, but also Latin America's "pink tide" more broadly. 
Post, Charles. 2011. The American Road to Capitalism: Studies in Class

Structure, Economic Development and Political Conflict, 1620-1877.

Leiden: Brill. ISBN 978-90-04-20104-0 Cloth: 141.00 USD. Pages: 298.

Reviewed by Jordy Cummings

York University

Charlie Post's The American Road to Capitalism is a magisterial text that deserves a close reading, in particular by scholars attempting to make sense of $20^{\text {th }}$ century capitalism in the United States. Only when armed with knowledge of the peculiarity of the American question can we begin to understand the specificity of a logic that continues to subsume everything in its wake. As well, the book is an explicit defense of the school of thought labeled "Political Marxism" (henceforth PM). Post consciously places his work in this growing body of knowledge that emphasizes historical specificity, empirical clarity and unintended consequences, thus a theory of social property relations. Like Robert Brenner on England or George Comninel on France, Post problematizes both standard and critical accounts of the making of American capitalism. One sees the unintended consequences and class struggles, on a regional and then finally national scale, subsequent to the Civil War. Given what some call the "Americanization" of global capital, the implications of this work are indeed far reaching.

In place of "Political Marxism," Post prefers "Capital-centric Marxism" (2), in that it takes its cues not from Marx's early stagism but from the multilinear specificity found in the three volumes of Capital. Thus there is a rejection of a deterministic theory of history, in which changes in social relations are produced by mere clashes between forces and relations of production. This is to critique the importation of such iron laws unto American history, in which case we see the American Revolution and Civil War being two stages in the American "bourgeois revolution." E.P. Thompson famously made the claim that one could not meta-theorize the discipline of historical materialism, rather, as Engels once said "the proof of the pudding is in the eating." This is to say that in order to gauge what constitutes the discipline is to examine its ontological suppositions, and in the case of "political" Marxism, none is more controversial than its allegedly narrow theory of capitalism, a criticism not entirely off the mark. With Post, finally, we have an explicit PM theory of capitalism.

Capitalism exists when "a class of non-producers owns and controls productive property," purchases labour power from wage workers - "direct producers who do not possess means of production" (40). Surplus value is extracted through the former's control of the production process. Commodified labour, means of production and outputs constitute a social property relation alongside inter-capitalist competition, which together necessitate both specialization and innovation. This mode of extracting surplus, 
capitalism, "shapes a labour process that is the basis of industrialization and its attendant social changes"(ibid.). In other words, Post's model is a sort of "ABC" of a Marxian theory of capitalism, yet in lieu of finding such capitalism budding in the interstices of non-capitalist social property relations, capitalism is only capitalism when all features are at the very least discernable, in particular the imperative of innovation and competition.

In place of this teleological idea of capitalism, Post uses the American experience to demonstrate that having a fuzzy model of capitalism will disallow the illumination of non-capitalist social relations and their attendant rules of reproduction. Particularly notable is his conceptualization of "non-capitalist independent household production" in which cheap if not free land allowed for commercial life to exist in a non-capitalist sense, that is to say, producers engaged in commodity exchange but had non-market access to the means of production and subsistence. English merchant capital indeed tried to "develop" its colonies by way of the marketization of land ownership, implicitly as imitation of how capitalism itself developed in the English countryside. Success or stalemate in fierce class struggles between household producers, farmers and artisans, often squatters, and merchants sometimes even took the form of armed rebellions. The resulting class settlements and uneven development rendered much of the United States dominated by non-capitalist artisanal or farm-based production for much of its early history.

Southern plantation slavery may well have been umbilically connected to the world market, but was emphatically not capitalist in either form or content. Formally, slavery was predicated upon the extraction of maximum absolute labour from slaves, whom as objects could be constituted as constant capital. As opposed to purchasing labour power from proletarians, Masters purchased labourers. This is to emphasize the crucial distinction between the labour discipline of actual violence or worse, in the context of slavery, and the "whip of starvation" in capitalism. The slave economy deprived planters of means with which to innovate due to the lack of ability to increase labour productivity. There was thus a mix of the co-operative labour processes and time management that marked later capitalism with the inability to shrink the labour force redolent of feudalism, though labourers (slaves) could be sold if they were redundant. In the last instance, the only way for Southern farmers to increase their yields was to geographically expand alongside increasing the workday to 14 hours. This produced a mid $19^{\text {th }}$ century conjuncture of increasing global demand for cotton, and a set of vertical and horizontal class struggles that culminated in the Civil War.

Surveying various histories and analyses of the Civil War, Post finds that alone among the ruptures that the Marxist tradition has called "bourgeois revolutions," the civil war indeed fits the classical schema, but it certainly cannot be reduced to such a conceptualization. Manufacturing as well as agrarian capital on one hand, expansionary slavery on the other, pitted not forces of production against relations of production, rather it pitted two discrete social property relationships, and the eventual victory of 
capitalism was an unintended consequence of both ruling classes acting to reproduce themselves, under conditions not merely of competition between each other, often taking on a political form around the still-burning issue of "states rights." It is equally important to examine the struggles from below, in the form of proletarian struggles in the North and slave revolts in the South. Of course, the North won, but it was not so simple and a real subsumption of southern labour under capital was resisted by former planters as well as freed slaves, the unintended consequence of this struggle being the non-capitalist sharecropping that dominated southern agriculture as recently as half a century ago.

How did these multifaceted class struggles shape the DNA of American capitalist social property relations? Post draws on Comninel's postulation that the French Revolution, if it had any democratic after-effects, these effects were "anticapitalist," such as rent and price controls. On one hand, the radical southern demand of 40 acres and a mule was not implemented. On the other hand, the urban proletariat, a vital support base for the north in the Civil War, gained a new found sense of confidence. Against a backdrop of newly confident capitalist classes, they mounted direct actions to shorten the working day. Yet when the new labour movement of the north came close to allying with a multiracial "Farmer's Alliance" of tenant farmers, Jim Crow laws and disenfranchisement, lynching and the Klan were brought in by the new alliance of former rivals - merchants and planters. The defeat of this coalition and the fragmentation of popular and working classes mars the development of working class political organizations in the United States to this day.

Bannerji, Himani. 2011. Demography and Democracy: Essays on Nationalism, Gender and Ideology. Toronto: Canadian Scholars' Press. ISBN 978-1-55130-389-5. Paperback: 34.95 CAD. Pages: 272.

Reviewed by Aziz Choudry McGill University

Himani Bannerji's latest book is as timely as it is wide-ranging, incisive and thought-provoking. Comprising seven essays written during the span of just over a decade, with a new, substantive introduction, the book sparkles with a genuine sense of freshness and vitality. Demography and Democracy is highly relevant to readers concerned with the ongoing impacts of neoliberal capitalism, communal violence and cultural nationalism, and contemporary struggles over democracy in India. But its scope reaches far beyond India's borders in elucidating how ethnic/religious cultural 
nationalisms and patriarchy are used in the interests of imperialism around the world, and facilitate the global depredations of capitalism.

As with her other work, Bannerji builds upon Marx's material method, especially as articulated in The German Ideology, and its elaboration and application through institutional ethnography, a Marxist feminist method of sociological inquiry developed by Dorothy Smith - particularly on the social organization of knowledge. Additionally, this book is a significant scholarly contribution containing dialogues with, and critiques of, various intellectual turns and schools of thought. She engages with a range of scholarship, including, among others, Antonio Gramsci, Edward Said, Frantz Fanon, Walter Benjamin, Raymond Williams and Bengali historians Sumit and Tanika Sarkar.

Those whose focus is not on India/South Asia should read it because of the theoretical and methodological richness of the discussions about ideology, the concepts and practices of nationalism, gender, identity, ethnicity, culture and nation. Bannerji's theoretical and critical explorations and reflections are relevant across a range of disciplines and contexts, resonating at local, national and global levels. The book pulls together her "attempts to understand the different dimensions, explanatory possibilities and political implications of Marx's method of historical materialism" (2). Her criticaltheoretical choices are motivated by "the defensible view that historical and social realities of the world are neither macro-spaces of free-floating imaginaries and abstractions nor bounded within micro-formations and spaces of geographically discrete cultural identities" (7).

Bannerji unpacks and differentiates between forms of nationalism for one of the book's central projects. She views Zionism as a religious cultural nationalism which has legitimated the occupation of Palestine and compares it with attempts made by Hindu supremacists in India to engage in a political project which seeks to construct nonHindus (Muslims) as foreign invaders, to expel them, and to legitimate pogroms against Muslims in Gujarat in 2002. For her, both Israel and India are cases of theocratic patriarchy as well as modern ethnic/demographic state projects which portray themselves as liberal democracies. She contrasts this kind of nationalism with the potential of "anticolonial or resistance nationalism" (12) based on social equality and self-determination, although her book does not elaborate on these in any detail.

Two chapters deal explicitly with gender relations, but Bannerji attends to patriarchy and brings a feminist lens to bear throughout the book. She strongly critiques bourgeois nationalisms' inherent patriarchal outlook on socio-political questions, as well as feminisms which see women as a singular entity, as a collectivity self-enclosed and separate from their overall social existence and subjectivities. She calls for patriarchy and gender justice to be seen within the wider space of revolutionary social criticism rooted in a demand for social justice.

Bannerji also scrutinizes the Subaltern Studies Group of theorists which has emerged among some networks of historians on India and beyond. Building on Sumit 
Sarkar, she is critical of an "epistemological shift which separates culture and ideology from class and social organization and yet claims to be writing history" (131). Further, she argues that Subaltern Studies scholars such as Partha Chatterjee legitimate various forms of violence against women, and that "subsum[ing] all issues of powered differences within a rhetoric of cultural nationalism, can only lead to new and internal forms of colonization" (176). She contends that the rightward swing in subaltern studies buoys supporters of an essentialist and anti-modernist national enterprise, cultural nationalism and ethnicized religio-communitarian state. She warns against fragmenting and separating culture, politics and economy, only for them to be added to each other when the need arises. She urges instead that we go past culturalist lenses, concepts, categories and meanings which obscure historical and social relations, citing the dangers of dehistoricizing history and instead relying on notions of culture, which inform and feed cultural nationalism.

Two of the book's chapters deal with Bengali poet, novelist, philosopher and playwright Rabindranath Tagore, and his visions of nationalism and decolonization. Bannerji maps the evolution of Tagore's views on decolonization, arguing that he opened up spaces in his novels, offering a "dynamic social and aesthetic pedagogy [which] marked a journey between what is and what ought to be" (219). Bannerji suggests that one can draw on Tagore's pedagogy fused with Marx's vision, analysis and politics to imagine an alternative vision of development and a new humanism.

I particularly appreciated the introduction and the final chapter entitled "The Tradition of Sociology and the Sociology of Tradition: The Terms of our Knowledge and the Knowledge Produced" - as excellent tools for teaching. In the latter, Bannerji strongly critiques the paradigm of tradition and modernity so prevalent in sociology as dehistoricized, degrounded and ideological categories which are implicated in capital, class, colonialism and imperialism. In sum, she has given us a rich book and reminds us what powerful tools historical materialism offers for analysis and action, indeed, for imagining and acting to bring about a better world. As Bannerji puts it: "[u]nravelling the constitutive entanglements of history, society, culture and politics allows us to arrive at claims about what surrounds us here and now, to some proximate truth claims about the past and the present, which is vital for any critical understanding and transformative action" (4). In sum, this book is a very welcome contribution to a sociology for changing the world. 
Wright, Erik Olin. 2010. Envisioning Real Utopias. London: Verso. ISBN: 978-1-84467-617-0. Paperback: 33.50 CAD. Pages: 394.

Reviewed by Jeff Noonan

University of Windsor

This wide-ranging and carefully argued text is Wright's contribution to the Real Utopias project that began under his general editorship in the early 1990s. His ambitious text exemplifies the goal of the project: to identify existing institutions and practices which prefigure a radical alternative to capitalism. The text advances a unified normative argument articulated in three interrelated parts: "Diagnosis and Critique," "Alternatives," and "Transformation."

"Diagnosis and Critique" begins by explaining the systematic ways in which capitalism harms people. In eleven eloquently and non-dogmatically defended theses, Wright supports the conclusion that a socialist alternative to capitalism is desirable because capitalism is systematically undemocratic, oppressive and unequal. The socialist alternative envisaged by Wright is a radically democratic, egalitarian society that combines economic with political justice in ensuring that the material conditions of "human flourishing" are satisfied for each and all. It is radically democratic to the extent that democracy extends throughout all those social institutions, especially, economic institutions, within which the life-horizons of people are shaped.

This reconstruction of the socialist vision maintains the Marxist tradition's commitments to extending democracy into economic life, to providing real opportunities for people to realize their capacities, and to ensuring the satisfaction of their needs, while widening the political roads by which these goals might be reached beyond revolutionary class struggle. The overall normative vision is inspiring and lucidly defended. Still, Wright, like much recent Marxist and left-liberal work (by István Mészáros, Michael Lebowitz, Martha Nussbaum and Thomas Pogge) that also employs the language of needsatisfaction and flourishing does not provide any explicit criterion by which needs might be distinguished from consumer demands or say anything about what limits natural lifesupport systems might impose upon the projects through which our capacities are rationally expressed in a "flourishing" life. Nevertheless, Wright's normative arguments are a convincing vindication of his thesis that socialism remains a desirable alternative to capitalism.

That socialism is desirable, however, does not prove that it is viable. The theoretical and practical heart of the book is the second part, "Alternatives," in which Wright examines a variety of existing practices and theoretical models for workable, noncapitalist social and economic institutions and relationships. He begins with a careful examination of the different forms of power-economic, state and social-at work in any society. He locates socialism at the opposite end of a continuum ranging from an ideal- 
type market society in which private economic power predominates. A fully socialist society would subordinate economic power to social power, the power of associated citizens and producers, and absorb state power into its radically democratic institutions. In Wright's "real utopia" the realization of either extreme is impossible. Any actual society will be a hybrid of economic, state and social power. The goal of socialists, he rightly contends, is to work progressively to subordinate as much economic and state power to social power as possible.

The alternatives he examines exemplify, to different degrees, the real possibility of building economic institutions which are governed by social power. Some examples illustrate alternative structures of motivation, for example, Wikipedia, whose creators contribute their time because they find the project intrinsically valuable, not because they are paid. Others explore actual democratic economic practices and institutions, like participatory budgeting in Porto Allegre, Brazil, or the Mondragon cooperatives in Spain. The section concludes with critical overviews of two theoretical alternatives to capitalism, Jon Roemer's model of market socialism and Michael Albert's participatory economics. Considered as a whole, this section is inspiring. Its examples of "real utopias" illustrate that not only is another world in the abstract possible, in many respects it is already actual, if only in piecemeal form.

As inspiring as Wright's analyses of these examples are, I could not but be struck by his complete silence as to unarguably the most important experiments in building democratic alternatives to capitalism today, those jointly underway in Venezuela and Bolivia, and the most plausible theoretical alternative to capitalism, Pat Devine's negotiated coordination economy (e.g. Devine 2002). As regards Venezuela and Bolivia, Wright does not even include a footnote explaining why he chose not to include them. It cannot be because he wanted to concentrate on European and North America examples, since Porto Allegre is in Brazil. There are certainly problems and challenges in each of these society-wide experiments in economic democratization, but that cannot explain why there is no mention of them, since Wright is candidly critical about all the examples he studies. He could have discussed one or both as critically as he felt was necessary. To say nothing about either in a book on real alternatives to capitalism is, I believe, a significant shortcoming.

The concluding section, "Transformation," opens with an instructive discussion of how societies, even exploitative and alienating ones, are able to reproduce themselves. While the means whereby compliance with existing norms is ensured are multiple and powerful, no society has proven capable of forever suppressing its contradictions. Social contradictions for Wright are spaces in which social power can grow, either as an alternative to state power, or as a force capable of channelling state power in democratic and egalitarian directions. While Wright is sceptical (but not dismissive) of the possibility of revolutionary overthrow of capitalist society in the West (ruptural transformation) he is more hopeful (but not naively so) about possibilities for interstitial and symbiotic 
transformation. Interstitial transformation works within the spaces not yet colonized by economic and state power to build new associative communities and institutions, while symbiotic forms of transformation use state power to solve problems for capital while also advancing social power. Social democracy is the classic example of symbiotic transformations. While there are perhaps still some Marxists who hold out hope for a traditional working class revolution against capital, it is difficult to disagree with Wright's general support for interstitial and symbiotic strategies as most appropriate to the context of political struggle in the developed capitalist world.

Notwithstanding the limitations I noted above, Wright's text is a productive synthesis of theory and practice, classic theories and novel developments, political imagination and clear-sighted realism about the challenges the socialist alternative faces. Overall, Envisioning Real Utopias is an important contribution to a most needed debate about what is to be done.

\section{References}

Devine, Pat. 2002. "Participatory Planning Through Negotiated Coordination." Science and Society. Vol. 66, No. 1. 